SAKAI SAMBAYAN — Jurnal Pengabdian kepada Masyarakat

\title{
PELATIHAN BAHASA INGGRIS KOMUNIKATIF BERBASIS GAME ANAK-ANAK DI PANTI ASUHAN AL FALAH YASMUBA
}

\author{
Novita Nurdiana ${ }^{1}$, Rafista Deviyanti ${ }^{2}$, Khairun Nisa ${ }^{3}$, Dian Shafwati ${ }^{4}$ \\ Program Studi Pendidikan Bahasa Inggris, \\ Jurusan Pendidikan Bahasa dan Seni, Fakultas Keguruan dan Ilmu Pendidikan, \\ Universitas Lampung \\ Penulis Korespondensi: sweetmoxer@gmail.com
}

\begin{abstract}
ABSTRAK
Kegiatan pengabdian kepada masyarakat (PKM) ini bertujuan membantu panti asuhan Al Falah Yasmuba, dengan memberi pelatihan bahasa Inggris komunikatif berbasis game anak-anak di yayasan tersebut mampu berkomunikasi dengan menggunakan bahasa Inggris secara lisan dengan lebih baik. Pencapaian tujuan tersebut dilakukan melalui pelatihan dengan metode meliputi: (1) Memberikan pelatihan dan workshop dengan menyajikan materi melalui tatap muka langsung mengenai pentingnya bahasa Inggris sebagai bahasa Internasional, (2) memberikan pelatihan bahasa Inggris komunikatif berbasis game kepada anak-anak Panti Asuhan Al Falah Yasmuba. Hasil penelitian menunjukkan bahwa pelatihan yang diberikan mampu meningkatkan pemahaman peserta terhadap kemampuan Bahasa Inggris. Setelah mengikuti pelatihan terlihat bahwa motivasi siswa meningkat dan ketertarikan terhadap pembelajaran Bahasa Inggris meningkat. Berdasarkan suasana pelatihan yang diamati pemateri pada saat pelatihan berlangsung, materi dan praktik games terbukti bisa membuat peserta pelatihan belajar bahasa inggris secara aktif, komunikatif, serta menyenangkan. Adapun saran yang dapat diajukan dari hasil program P2M, bagi para pengajar bahasa inggris metode berbasis game ini dapat digunakan dikelas pada situasi apapun baik formal maupun non formal dan terbukti menyenangkan bagi murid dalam belajar bahasa inggris.
\end{abstract}

Kata Kunci: Pelatihan Bahasa Inggris, komunikatif, game

\section{Pendahuluan}

Penguasaan hardskill dan softskills yang mumpuni merupakan suatu keharusan di era digital saat ini supaya dapat bersaing dengan bangsa lain. Hal ini menjadikan Bahasa Inggris menjadi salah satu kemampuan softskills yang penting untuk dikuasai sebagai Bahasa asing. Sebagai lingua franca, hampir semua masyarakat menggunakan Bahasa Inggris untuk berkomunikasi di forum internasional. Komunikasi yang baik akan menghasilkan banyak keuntungan di berbagai bidang. Sebaliknya, ketidaklancaran dalam berkomunikasi akan menghasilkan kegagalan di banyak aspek.

Mengingat pentingnya peran yang dimilikinya, Bahasa Inggris perlu diajarkan sedini mungkin baik secara formal maupun informal. Menurut para ahli, periode terbaik untuk belajar Bahasa asing adalah pada usia dini. Dalam penelitiannya, Matsuoka dan Smith (2008) mengatakan bahwa usia sangat berpengaruh pada Vol 5 No 2 Juli 2021 pemerolehan Bahasa ke dua. Secara umum, diyaini bahwa anak usia dini memiliki keuntungan berupa "plasticity" dibandingan orang dewasa dalam mempelajari Bahasa. Senada dengan Matsuoka dan Smith, Krashen, Long dan Scarcella (di LarsenFreeman, 1991) mengatakan bahwa usia lebih tua lebih cepat mempelajari Bahasa ke dua, namun usia lebih muda lebih baik.

Lebih lanjut, Pinter (2006) menyatakan bahwa keuntungan anak-anak yang berumur lebih muda mempelajari Bahasa baru adalah pemahaman intuitif Bahasa mereka dan kemampuan mereka untuk lebih terbiasa dengan sistem fonologis Bahasa baru karena mereka lebih peka terhadap bunyi, ritme dan pola intonasi. Anak-anak menikmati dalam meniru dan mereka memiliki tingkat kecemasan yang lebih sedikit dibandingan pembelajar dewasa. Seperti yang dikatakan oleh Pinter (2006), semua penjelasan tentang "plasticity" otak yang telah dijabarkan di atas, 
dikenal dengan Critical Period Hypothesis $(\mathrm{CPH})$ yang dipopulerkan oleh Lenneberg (1967).

Selaras dengan teori ini, di Indonesia, bahasa Inggris dimulai pada tahun 1994 secara resmi diajarkan di tingkat sekolah dasar sebagai salah satu mata pelajaran wajib muatan lokal dalam kurikulum sekolah dasar. Dalam perjalanannya, pada tahun 2013 melalui kurikulum 2013, posisi bahasa Inggris mengalami pergeseran di mana bahasa Inggris dikelompokkan menjadi salah satu pelajaran ekstra kurikuler. Hal ini berarti bahwa mata pelajaran bahasa Inggris dapat tetap diajarkan sebagai mata pelajaran pilihan dengan tujuan untuk membangun dan menunjang pendidikan karakter siswa tergantung kebijakan sekolah masingmasing.

Panti Asuhan Al Falah Yasmuba merupakan suatu lembaga kesejahteraan sosial yang memberikan pelayanan kepada anak-anak asuh yang ada di yayasan dengan cara menyantuni dan pengentasan anak-anak agar anak-anak tersebut mendapatkan hak-haknya. Yayasan ini terletak di kawasan Sukarame, Bandar lampung. Dengan adanya yayasan tersebut anak mendapatkan pelayanan pengganti orang tua sehingga anak-anak tersebut dapat tumbuh dan berkembang dengan baik secara fisik, psikologis dan sosial. Sehingga anak-anak merasa mendapatkan keluarga yang utuh dan dapat terpenuhinya kebutuhan-kebutuhan anak termasuk kebutuhan untuk memperoleh ilmu pengetahuan sebagai bekal mereka kelak untuk bisa hidup mandiri. Salah satu ilmu pengetauan yang penting untuk diajarkan kepada mereka sebagai bekal untuk bersaing di era globalisasi seperti sekarang ini adalah pelatihan berbahasa Inggris. Sebagai bahasa internasional anak-anak di panti asuhan Al Falah Yasmuba juga tentunya mempunyai hak untuk mempelajari bahasa Inggris sebagai alat komunikasi global.

Di dalam pembelajaran berbahasa Inggris kemampuan berbicara menjadi aspek yang sangat penting disamping penguasaan komunikasi secara tertulis. Tetapi pada kenyataannya masih banyak sekali anak-anak yang sulit berkomunikasi menggunakan bahasa Inggris secara lisan termasu anak-anak di panti asuhan Al Falah Yasmuba. Berdasarkan observasi sederhana yang telah dilakukan sebelumnya, mayoritas anak-anak di panti asuhan ini masih sangat sulit untuk bisa menyampaikan gagasan maupun ide secara

Vol 5 No 2 Juli 2021 sederhana dengan menggunakan bahasa Inggris. Padahal mereka telah mendapatkan pembelajaran bahasa Inggris di bangku sekolah. Sebagian besar anak-anak di panti asuhan Al Falah Yasmuba ini mengeyam pendidikan formal mulai dari pendidikan dasar hingga pendidikan tinggi. Tetapi mengapa rata-rata mereka masih kesulitan berkomunikasi menggunakan bahasa Inggris secara lisan. Salah satu faktor penyebabnya adalah teknik pengajaran yang digunakan tidak memotivasi anakanak untuk belajar dengan nyaman dan menyenangkan. Umumnya mereka mendapatkan suasana pembelajaran yang monoton serta tidak menarik, sehingga kemampuan mereka pun sulit untuk berkembang. Salah satu upaya untuk mengatasi hal tersebut adalah dengan menciptakan suasana pembelajaran bahasa Inggris yang asyik, menarik dan menyenangkan. Sehingga mampu memotivasi mereka untuk meningkatkan kemampuannya. Pembelajaran yang menyenangkan ini bisa diberikan menggunakan permainan (game).

Ada beberapa alasan mengapa permainan atau games baik digunakan dalam proses belajar mengajar bahasa Inggris. Menurut Brewster, dkk. (2004) anak-anak menyukai game karena selain menyenangkan dan memberikan motivasi, game juga bisa sebagai sarana mempraktekan kemampuan empat ketrampilan berbahasa: mendengar, berbicara, membaca dan menulis. Berikut adalah beberapa manfaat game untuk pembelajaran menurut Brewster (1999) dan kawankawan: 1) Game menambah variasi situasi belajar; 2) Game merubah ritme pelajaran dan membantu menjaga motivasi siswa; 3) Game membuat pelajaran yang formal menjadi lebih santai dan membantu memperbaharui energi siswa; 4) Game menyediakan sarana praktek secara tidak langsung untuk pola- pola bahasa yang khusus, kosa kata, dan pengucapan; 5) Game dapat meningkatkan jangka waktu konsentrasi, konsentrasi, ingatan, kemampuan mendengar dan membaca; 6) Siswa terdorong untuk berpartisipasi; siswa yang pemalu bisa dimotivasi untuk berbicara; 7) Game meningkatkan komunikasi antar siswa dan memberikan kesempatan mempraktekan fluency dan mengurangi dominasi guru di dalam kelas; 8) Game dapat membantu menciptakan suasana yang menyenangkan dan mengurangi antara guru dan siswa; 9) Game dapat mengungkap kelemahan dan kebutuhan bahasa lebih lanjut; 10) Game dapat 
membantu memotivasi dan meningkatkan kemampuan menulis siswa dengan cara memberikan kontek dan tujuan pembaca yang nyata.

Berdasarkan uraian dan penjelasan diatas, diadakan lah pelatihan ini yang bertujuan membantu panti asuhan Al Falah Yasmuba, dengan memberi pelatihan bahasa Inggris komunikatif berbasis game anak-anak di yayasan tersebut mampu berkomunikasi dengan menggunakan bahasa Inggris secara lisan dengan lebih baik.

\section{Metode Pelaksanaan Pengabdian}

Untuk memecahkan permasalahan dalam kegiatan pengabdian kepada masyarakat ini, metode pelaksanaan yang akan digunakan meliputi: (1) Memberikan pelatihan dan workshop dengan menyajikan materi melalui tatap muka langsung mengenai pentingnya bahasa Inggris sebagai bahasa Internasional, (2) memberikan pelatihan bahasa Inggris komunikatif berbasis game kepada anak-anak Panti Asuhan Al Falah Yasmuba

Beberapa prosedur yang akan dilakukan dalam kegiatan pengabdian kepada masyarakat ini adalah sebagai berikut: (1) Kegiatan ceramah dan tanya jawab program pengembangan diri bagi anak-anak tentang pentingnya belajar bahasa Inggris, (2) penyajian materi bahasa Inggris berbasis game baik teori maupun praktik kepada anak-anak Panti Asuhan Al Falah Yasmuba. Acuan kegiatan pelatihan ini dapat diilustrasikan sebagai berikut:

1. Untuk mengetahui kondisi awal kemampuan peserta pelatihan secara keseluruhan di atas kertas, maka sebuah pre-test akan dilaksanakan terlebih dahulu menggunakan lembar evaluasi.

2. Perlakuan pelatihan. Setelah pre-test dilaksanakan, maka para peserta akan diberikan perlakuan atau pelatihan bahasa Inggris pariwisata komunikatif melalui metode simulasi, dialog dan bermain peran, serta diskusi.

3. Setelah perlakuan dilaksanakan, maka sebuah post-test akan dilakukan di akhir kegiatan untuk melihat peningkatan kemampuan bahasa Inggris peserta pelatihan menggunakan lembar evaluasi.

Lembar observasi digunakan untuk mengevaluasi kemampuan peserta sebelum dan sesudah pelatihan dilakukan. Observasi dilakukan pada beberapa aspek yang meliputi:

Vol 5 No 2 Juli 2021 penyampaian content $(40 \%)$; (2) fluency $(20 \%) ;(3)$ pronunciation dan intonation (20); dan (4) appearance (20\%). Selain itu, evaluasi juga akan dilakukan melalui wawancara yang akan dilakukan di akhir kegiatan. Tujuan wawancara ini adalah untuk mengetahui tanggapan dan hambatanhambatan yang mungkin dihadapi oleh peserta sebagai saran untuk kegiatan selanjutnya.

\section{Hasil dan Pembahasan}

Pelaksanaan kegiatan pelatihan ini membutuhkan waktu 3 dilaksanakan di Panti Asuhan Al Falah Yasmuba pada tanggal 7, 14, dan 21 Agustus 2020. Peserta pelatihan adalah siswisiswi SMP di Panti Asuhan Al Falah Yasmuba. Secara keseluruhan peserta pelatihan berjumlah 12 orang. Kegiatan dimulai dengan peserta diukur suhu tubuhnya satu persatu sebelum memasuki ruang pelatihan sesuai dengan protocol kesehatan covid-19. Peserta juga diwajibkan memakai masker sesuai dengan protocol kesehatan covid-19. Jarak tempat duduk pun diatur sedemikian rupa mengikuti protocol kesehatan covid-19/social distancing. Kegiatan pertama dimulai dengan pemateri memberikan materi terkait games kepada peserta. Lalu masing-masing pemateri memberikan pre-test berupa tanya jawab menggunakan bahasa inggris untuk mengukur kemampuan speaking siswa dan keaktifan peserta.

Dalam pelatihan ini dilakukan tahap evaluasi untuk mengevaluasi pemahaman dan keterampilan peserta terhadap penyusunan Rencana Pelaksanaan Pembelajaran. Tes pemahaman peserta terhadap materi yang telah disampaikan dengan melakukan pretes dan postes. Sebelum pembelajaran dimulai, peserta diberi pretes untuk mengetahui pemahaman awal terhadap materi-materi yang akan disampaikan. Selanjutnya, setelah seluruh proses pembelajaran selesai peserta diberi postes.

Kemampuan pemahaman materi saat pretes yaitu 4 peserta mendapat skor yang berada dalam rentang 60-74 dengan kategori cukup dan 8 peserta mendapat skor antara 40-59 dengan kategori kurang, serta tidak ada peserta yang masuk kategori baik sekali, baik, dan gagal. Nilai rata-rata pada pretes sebesar 55 dengan kategori kurang. Selanjutnya, pada saat postes skor yang diperoleh yaitu 1 orang mendapat skor 75-84 (Baik), 7 orang mendapat skor 60-74 (cukup), dan 4 orang mendapat skor 40-59 (kurang). Nilai rata-rata saat postes sebesar 65 dengan kategori baik sekali. 
Berdasarkan skor yang diperoleh peserta pelatihan saat pretes dan postes, kemampuan peserta pelatihan terlihat meningkat. Hal ini menunjukkan bahwa Pelatihan yang diberikan mampu meningkatkan pemahaman peserta terhadap kemampuan Bahasa Inggris.

Untuk mengetahui tanggapan peserta pelatihan, kami mengadakan survei dengan menggunakan intervew. Berdasarkan survei kepuasan peserta jawaban yang diberikan oleh peserta pelatihan setelah pelatihan selesai, diperoleh beberapa hal berikut ini.

1. Peserta menganggap pelatihan ini sangat berguna bagi pesrta untuk mendapatkan materi yang menarik dalam pembelajaran Bahasa Inggris.

2. Peserta menganggap pelatihan ini bermanfaat dalam memotivasi peserta mengikuti pelatihan maupun mempelajari Bahasa Inggris.

3. Peserta menganggap pelatihan ini sangat berpengaruh terhadap pembelajaran Bahasa Inggris.

4. Peserta menganggap pelatihan ini cukup efektif untuk pembelajaran di tingkat SMP.

5. Peserta merasa sangat puas terhadap pelayanan panitia.

6. Peserta merasa sangat puas terhadap strategi penyampaian materi yang digunakan fasilitator.

7. Peserta merasa sangat puas terhadap bimbingan fasilitator.

Berdasarkan survei kepuasan peserta pelatihan, maka dapat disimpulkan bahwa peserta merasa puas terhadap materi pelatihan, pelayanan panitia, dan strategi penyampaian materi dan bimbingan fasilitator.

\section{Kesimpulan}

Adapun simpulan yang dapat ditarik setelah pelaksanaan berdasarkan hasil dan pembahasan maka dapat disimpulkan beberapa hal. Yang pertama, berdasarkan hasil pretes dan postes diperoleh skor rata-rata yaitu 55 dan 84 sehingga dapat dikatakan kemampuan peserta pelatihan terlihat meningkat. Hal ini menunjukkan bahwa materi yang diberikan pada pelatihan bahasa inggris komunikatif berbasis game anak-anak di panti asuhan al- falah yasmuba berhasil meningkatkan pemahaman peserta terhadap materi bahasa inggris khususnya materi skill speaking. Dengan demikian, pelatihan ini dapat dikatakan berhasil pula dalam menambah pengetahuan serta pengalaman peserta dalam mengenal games bahasa inggris serta materi bahasa inggris.

Berdasarkan suasana pelatihan yang diamati pemateri pada saat pelatihan berlangsung, materi dan praktik games terbukti bisa membuat peserta pelatihan belajar bahasa inggris secara aktif, komunikatif, serta menyenangkan. Terbukti dari respon peserta didik yang mengikuti jalannya pelatihan sepenuhnya tanpa absen serta tidak terlihat satupun yang kurang aktif dan diam saja.

Berdasarkan survei kepuasan peserta pelatihan, maka dapat disimpulkan bahwa peserta merasa puas terhadap materi pelatihan, pelayanan panitia, dan strategi penyampaian materi.

\section{Daftar Pustaka}

Achmad, S. (2012). Pelatihan Kepariwisataan Dan Bahasa Inggris Praktis Bagi Remaja Dan Praktisi Pariwisata Pantai Olele Kecamatan Kabila Bone Kabupaten Bone Bolangol. Pengabdian Masyarakat-PNBP.

Brewster, J., Ellis, G., Girard, D.(2004). The Primary English Teacher's Guide. China. Penguin English Guides.

Claire,E. (1988). ESL Teacher's Activities Kit. New Jersey. Prentice Hall.

Harmer, Jeremy. (2007). The Practice of English Language Teaching. Longman ELT; $4^{\text {th }}$ Edition.

Littlewood, W. (1981). Communicative Language Teaching. Cambridge: Cambridge University Press.

Pateda, M. (1990). Sosiolinguistik. Yogyakarta: Gadjah Mada University Press.

Sinaga, T, dkk (2019). Pelatihan Bahasa Inggris Pariwisata Komunikatif Bagi Anggota Karang Taruna Tunas Muda Pekon Kiluan Muda Negeri Kabupaten Tanggamus. Pengabdian Masyarakat-PNBP.

Webster Merriem, (1986). Webster's Third New International Dictionary. Springfield, Merriem Websterinc 